\title{
CEB-FIP モデルを改良した高強度コンクリート構造部材の 力学特性発現モデル

\author{
IMPROVED CEB-FIP PREDICTION MODELS FOR DEVELOPMENTS \\ OF COMPRESSIVE STRENGTH AND YOUNG'S MODULUS \\ OF HIGH-STRENGTH CONCRETE IN STRUCTURE
}

\author{
橋田 浩*, 黒田泰弘**, 山崎庸行*** \\ Hiroshi HASHIDA, Yasuhiro KURODA and Nobuyuki YAMAZAKI
}

\begin{abstract}
Experiments were carried out on high-strength concrete specimens subjected to temperature rise due to heat of hydration in structure in order to discuss the prediction models for their early-stage mechanical properties, i.e., compressive strength and Young's modulus. The concrete maturity is estimated by the equivalent age specified in CEB-FIP Model Code 1990. The developments of mechanical properties can be fairly expressed by the present model curves, regardless of the temperature histories, derived from adding a parameter for final setting time to the equations specified in the Code. Influences of water to cement ratio and type of cement on the model and reduction of the development in structure to the standard specimen cured in water at $20^{\circ} \mathrm{C}$ are also discussed.
\end{abstract}

Keywords : high-strength concrete, prediction model, temperature history, compressive strength, Young's modulus, maturity, final setting 高強度コンクリート, 予測モデル, 温度履歴, 圧縮強度, ヤング係数, マチュリティ, 凝結の終結

\section{1. はじめに}

高強度コンクリートは単位セメント量が多いため、構造部材は水 和発熱による温度履歴を受け、圧縮強度やヤング係数などの力学特 性の発現性状は、標準養生供試体とは異なってくる。しかしなが ら、一般には、標準養生供試体以外の力学特性デー夕は不十分であ り、構造設計や施工計画において実構造部材の若材龄における力学 特性を予測する場合などに活用できるデー夕は少ない。したがっ て、標準養生供試体の基本データから実構造部材の力学特性発現を 評価できるモデルがあれば非常に有意義である。信頼性の高いこの ようなモデルが構築されれば、実大規模の確認実験をすることな

く、高強度コンクリート構造体の強度管理も可能となる。また、温 度応力や最近問題が指摘され始めている自己収縮応力の評価にも力 学特性発現モデルは欠かせない。

しかしながら、我が国には、一般化された力学特性発現モデルは 指針類に整備されていないため、既往の類似のデータや研究結果を 参考にする、ケース・バイ・ケースの実験で確かめる、欧米諸外国 のコードを利用するなどの方法で対処することになる。欧米のコー ドにしても、我が国のコンクリート材料との適合性、温度履歴を受 ける構造部材への拡張性などは定かでない。

以上の背景から、本研究は、部材温度履歴を受けた供試体の力学
特性実験（実験1）、水セメント比やセメントの種類をパラメータ にした実験（実験2）結果に基づき、高強度コンクリートの初期材 齢から材齢91日程度までの圧縮強度ならびにヤング係数発現モデル を提案するものである。ここでの提案モデルは、温度履歴を受けた 場合のマチュリティの妥当性と標染盖生材齢28日の力学特性を基準 に発現式が構成されていることなどの理由から、CEB-FIP Model Code 90")基本としている。また、本実験対象は主に高強度コンク リートに限られているが、提案モデルは普通強度レベルのマスコン クリートにも有効であることも併せて示す。なお、本研究では、基 礎、柱など比較的厚い部材を対象としており、力学特性に及ぼす養 生中の乾燥の影響は考慮していない。

\section{2. 実験1 \\ 2.1 概要}

実験1は、表ー1、表-2に示す普通ポルトランドセメント （OPC）または高ビーライト系セメント（BPC）を用いた2種類の 高強度コンクリート供試体の標準養生ならびに構造部材としての温 度履歴を受けた場合の力学特性発現を把握することを目的とした。 表一2のf、E $E_{c}$ はそれぞれ標準養生材齢28日の圧縮強度とヤング係数 である。

\footnotetext{
* 清水建設㑣技術研究所 主任研究員 - I 修

** 清水建設(侏技術研究所研究員 - 工修

*** 清水建設(桻技術研究所主席研究員・工临
}

Institute of Technology, Shimizu Corporation, M. Eng.

Institute of Technology, Shimizu Corporation, M. Eng.

Institute of Technology, Shimizu Corporation, M. Eng. 
コンクリートは、実機プラントで練り混ぜ、アジテータ車で実験 場に輸送したものから採取して供試体とした。供試体採取は練混ぜ 後約2時間を経過して完了しており、採取時のコンクリート温度は $\mathrm{OPC}$ で約 $30^{\circ} \mathrm{C} 、 \mathrm{BPC}$ 約 $25^{\circ} \mathrm{C}$ であった。供試体は採取後から、 $20^{\circ} \mathrm{C}$ 一定の恒温槽、または上下面を断熱した $1 \times 1 \times 1 \mathrm{~m}$ の模擬部材，(図- 1）の中心部または隅角部の温度履歴を追随させた水槽内で封かん 養生とした。20 $\mathrm{C}$ 一定の恒温槽で養生した供試体は、材齢3日以降 $20^{\circ} \mathrm{C}$ 水中養生としており、以後これを標準養生供試体と見なして検 討する。また、これらの供試体と同様の養生を行った試料につい て、JIS A 6204付属書1に染拠してプロクター貫入抵抗試験を行い凝 結時間を測定した。

各養生供試体の圧縮強度ならびにヤング係数は、練混ぜ完了後 3、6、12、18、24、36時間、2、3、7、28、91日に測定した。ヤン グ係数は、圧縮強度試験における応力-ひずみ曲線から求めた割線ヤ ング係数である。ひずみは、材齢1日以前の供試体については試験 機の載荷板間の変位量から求め、材齢1日以降はコンプレッソメー タで測定した。

\section{2 結果および考察}

1)マチュリティ則の比較

各養生供試体の温度履歴を図一2に示す。このように養生温度が 異なるコンクリートの強度発現を評価するためにマチュリティの概

\section{表一1 実倹1の使用材料}

\begin{tabular}{|c|c|c|}
\hline 材料 & 記号 & 種類、物性 \\
\hline \multirow[t]{2}{*}{ セメント } & $\mathrm{OP}$ & $\begin{array}{l}\text { 普通ボルトランドセメント } \\
\text { 比重3.16、比表面積 } 3 ; 400 \mathrm{~cm}^{2} / \mathrm{g}\end{array}$ \\
\hline & $\mathrm{BP}$ & $\begin{array}{l}\text { 高ビーライト系セメント } \\
\text { 比重3.21、比表面積 } 4,170 \mathrm{~cm}^{2} / \mathrm{g}\end{array}$ \\
\hline 細骨材 & $S$ & $\begin{array}{l}\text { 砕砂、山砂の混合砂 } \\
\text { 比重2.62、吸水率 } 1.52 \% \text { 、粗粒率2.78 }\end{array}$ \\
\hline 粗骨材 & $G$ & $\begin{array}{l}\text { 硬質砂岩砕石（最大粒径 } 20 \mathrm{~mm} \text { ) } \\
\text { 比重2.68、吸水率 } 0.72 \% \text { 、粗粒率 } 6.58\end{array}$ \\
\hline 混和浏。 & SP & ポリカルボン酸系高性能AE減水剤 \\
\hline
\end{tabular}

表一2 実験 1 調合

\begin{tabular}{|c|c|c|c|c|c|c|c|c|}
\hline 種類 & $W / C$ & $s / a$ & $W$ & $C$ & $S$ & $G$ & $\begin{array}{c}f_{c} \\
(\%)\end{array}$ & $\begin{array}{c}E_{c} \\
(\%)\end{array}$ \\
\cline { 4 - 8 } & \multicolumn{5}{|c|}{$\mathrm{kg} / \mathrm{m}^{3}$} & & $\left(\mathrm{~N} / \mathrm{mm}^{2}\right)$ & $\left(\times 10^{4} \mathrm{~N} / \mathrm{mm}^{2}\right)$ \\
\hline OPC & 28.0 & 44.4 & 165 & 589 & 719 & 922 & 96.1 & 3.92 \\
\hline BPC & 27.0 & 47.0 & 170 & 630 & 741 & 854 & 92.7 & 3.68 \\
\hline
\end{tabular}

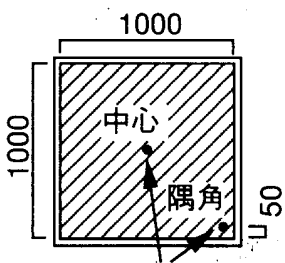

蒀度測定位置

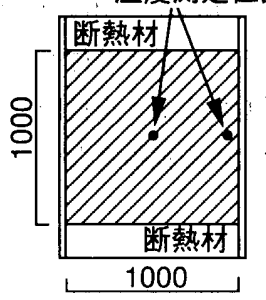

図-1 温度追随用模擬部材

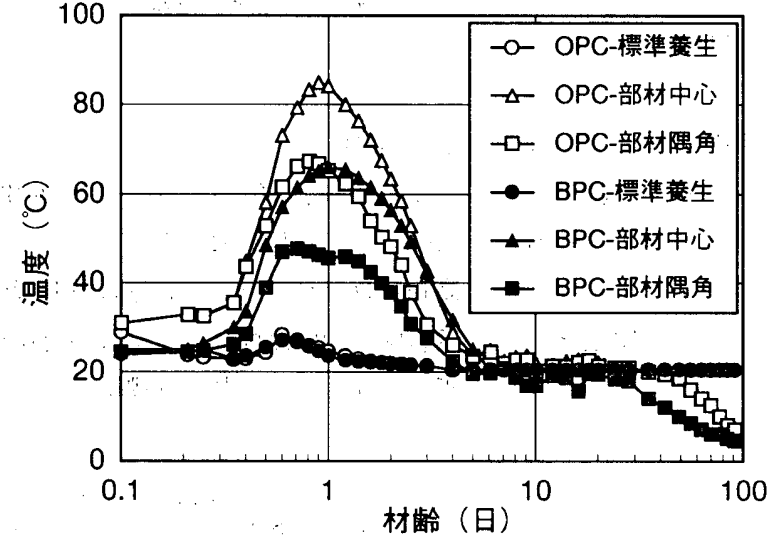

図一2 供試体の温度变化
念が利用される。マチュリティ則としては、積算温度方式、アレニ

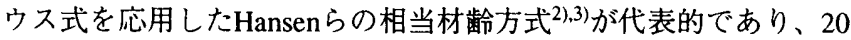
${ }^{\circ} \mathrm{C}$ 養生を基涑にした場合の等価な材齢 $t$ （日）は、それぞれ次式の ように表される。

積算温度方式

$$
t_{e}=\int_{0}^{t}\left(\frac{T+10}{30}\right) d t
$$

相当材齢方式

$$
t_{e}=\int_{0}^{t} \exp \left[\frac{E}{R}\left(\frac{1}{293}-\frac{1}{273+T}\right)\right] d t .
$$

ここに、 $T=d t$ 時間中の養生温度 $\left({ }^{\circ} \mathrm{C}\right) 、 d t=$ 時間（日）、 $R=8.314$ $(\mathrm{J} /(\mathrm{mol} \cdot \mathrm{K}))$ (ガス定数 ) 、Eは活性化エネルギー（化学反応エネル ギーとしての水和熱でセメント固有の値）で、以下の值となる。

$$
\begin{array}{ll}
T<20^{\circ} \mathrm{C} て ゙ & E=33.5+1.47(20-T)(\mathrm{kJ} / \mathrm{mol}) \\
T \geqq 20^{\circ} \mathrm{C} \text { で } & E=33.5(\mathrm{~kJ} / \mathrm{mol})
\end{array}
$$

また、CEB-FIP Model Code $90^{1)}$ に採用されているマチュリティ則 は、相当材齢方式を簡易化した以下の式であり、平成8年版土木学 会コンクリート標準示方書・設計編のクリープの項に有効材齢と称 して取り入れられている。

$$
t_{T}=\sum_{i=1}^{n} \Delta t_{i} \cdot \exp \left[13.65-\frac{4000}{273+T\left(\Delta t_{i}\right) / T_{0}}\right]
$$

ここに、 $t_{T}=$ 有効材齢（日）、 $T\left(\Delta t_{i}\right)=$ 期間 $\Delta t_{i}$ における温度 $\left({ }^{\circ} \mathrm{C}\right) 、 \Delta t_{i}=$ 温度 $T$ の継続時間（日）、 $T_{0}=1^{\circ} \mathrm{C}$ である。CEB-FIPの 有効材齢（以下、単に有効材齢という），と相当材齢との違いは、前 者が $20^{\circ} \mathrm{C}$ 以下での活性化エネルギーの変化を考慮していない点であ る。これらのマチュリティを比較して表一3に示す。養生温度 $20^{\circ} \mathrm{C}$ 以上では、相当材齢および有効材齢は、積算温度に比べ、温度の影 響をより強く評価している。

図ー3、図ー4にOPC、BPCの圧縮強度およびャング係数の発現 を、材齢、積算温度材齢または有効材齢との関係で示す。マチュリ ティ則により温度条件に係わらず力学特性発現を統一的に表せるよ うになるが、特に有効材齢をマチュリティとすると、温度履歴を受 けた供試体でも、材齢7日程度までの初期材龄では標準養生供試体 とほとんど同一の曲線で表せることがわかる。また、模擬部材の中 心部と隅角部における温度履歴の差異が力学特性発現に及ほす影響 は、最終材齢までほとんど認められなかった。 
2) 発現モデル式

マチュリティと圧縮強度の関係を表す発現モデルとしては、対数 曲線型、指数曲線型、双曲線型などが提案されている。これらのな かで、次式に示す指数曲線型のCEB-FIPモデル ${ }^{1)}$ は、標染養生材齢 28日の特性を基準とし、圧縮強度とヤング係数のモデルに共通性が あることから、実用性が高いと考えられる。

圧縮強度発現モデル

$$
f(t)=f_{c} \cdot \exp \left\{s\left[1-\left(28 /\left(t / t_{1}\right)\right)^{0.5}\right]\right\}
$$

ヤング係数発現モデル

$$
E(t)=E_{c} \cdot \exp \left\{s / 2\left[1-\left(28 /\left(t / t_{1}\right)\right)^{0.5}\right\}\right.
$$

ここに、 $f_{c}, E_{c}$ =標準養生材齢28日における圧縮強度またはヤング係 数、 $s=$ セメントの種類の影響による係数で、発現の相対速度を表す 係数（ただし、值が小さいほど発現が速く、ヤング係数は圧縮強度 の2倍の発現速度であることを意味している）、 $t=$ 有効材龄(日)、 $t_{1}=1$ 日である。また、 $s$ 值として、早強高強度系セメントは0.2、普

通・早強系セメントは 0.25 、低発熱系セメントは0.38が示されてい
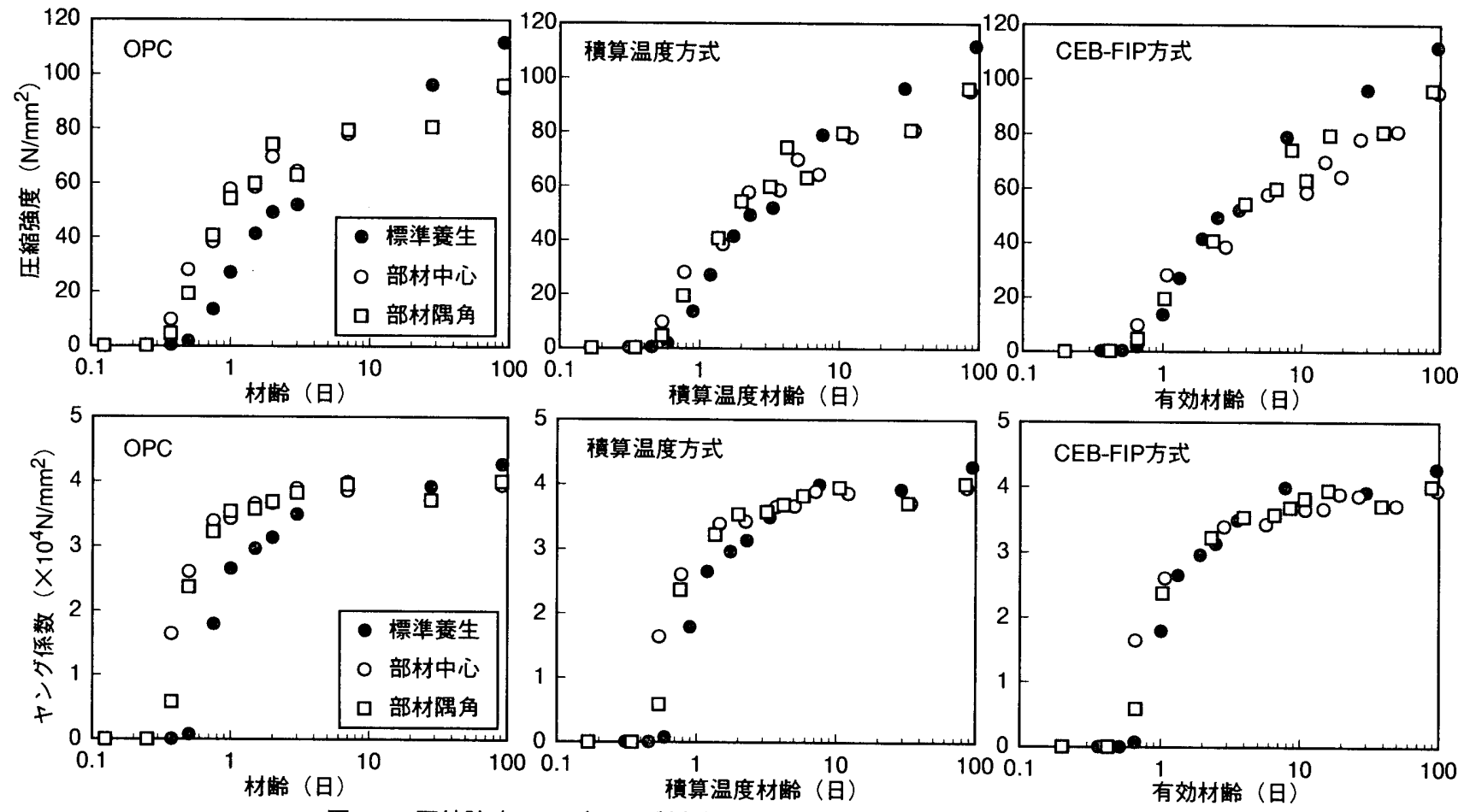

図一3 圧縮強度およびヤング係数発現におけるマチュリティの比較：OPC
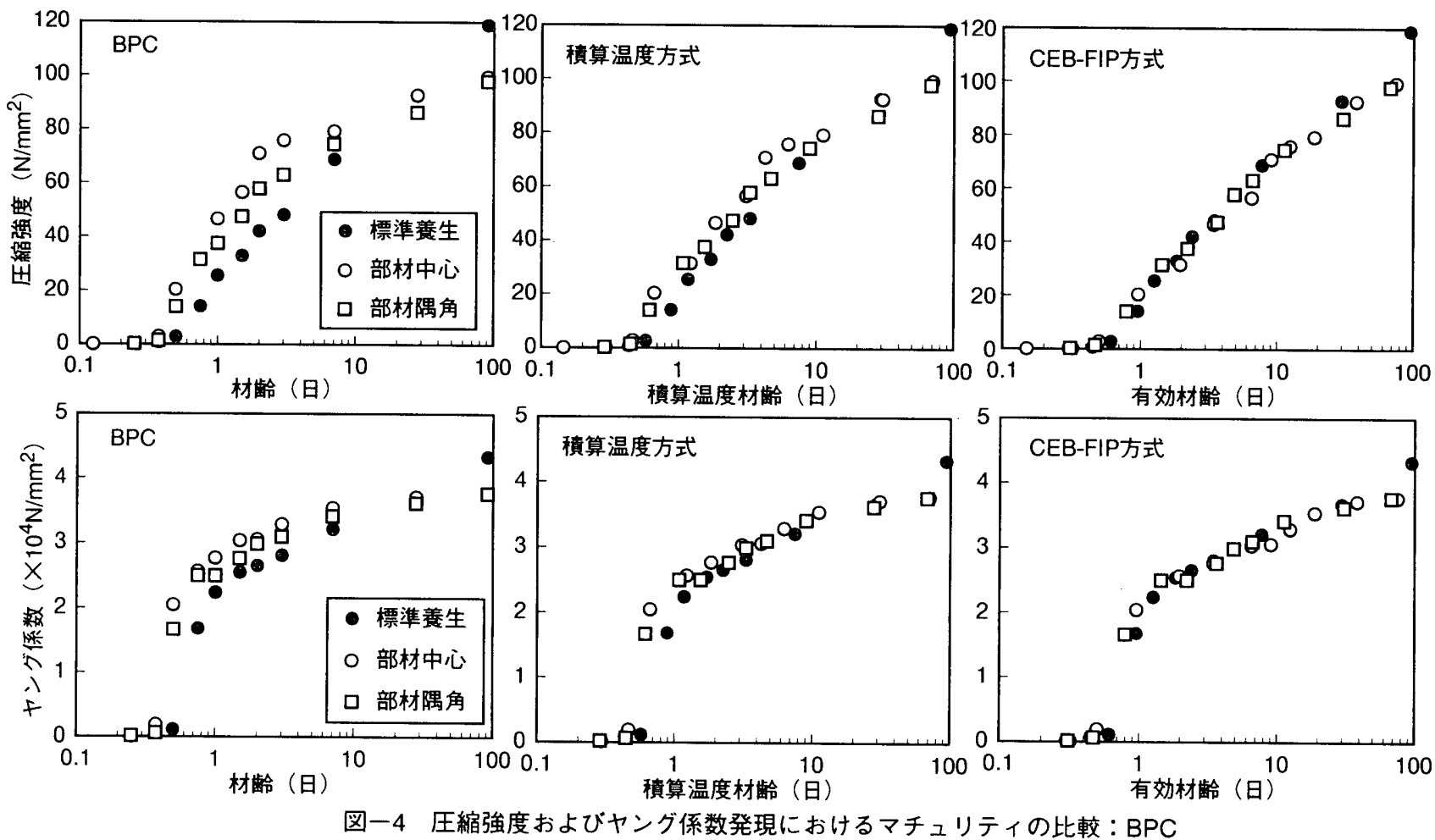

冈ー4 圧縮強度およびヤング係数発現におけるマチュリティの比較：BPC 

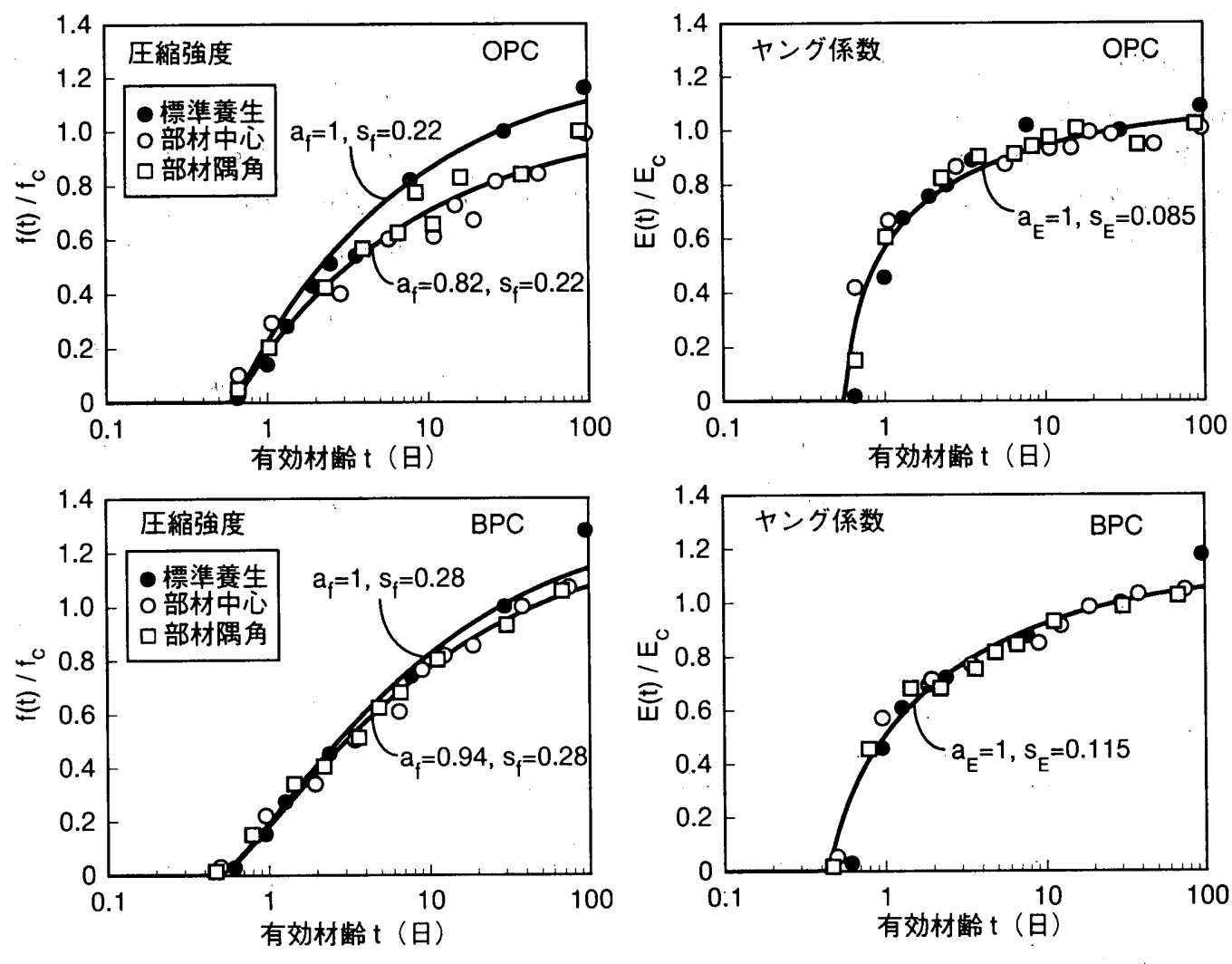

図一5 圧縮強度およびヤング係数の測定值と発現モデル：実験1

る。

ただし、筆者が文献4)で指摘しているように、CEB-FIPモデルの ままでは有効材齢1日程度までの適合性は良好でなく、特性発現の 起点として凝結時間を導入する必要がある。後述する実験 2 の結果 も含め種々検討した結果、圧縮強度発現、ヤング係数発現とも凝結 の終結時間を起点と考えることで、モデルの適合性が向上すること が確認された。また、初期高温履歴を受けると、水和生成物の形態 の変化 ${ }^{5}$ 、水和反応の停滞(6により、標準養生に比べ長期的な強度増 進が小さいことが一般に知られている。低水セメント比のコンク リート部材であれば、自己乾燥による水和の停滞も考えられる。こ れらの影響を定量化することは現状では困難であるが、構造部材を 対象としたモデルとしては考虑する必要がある。以上の検討から、 次のようなCEB-FIPモデルの改良式を提案できる。

圧縮強度発現

$$
f(t)=a_{f} \cdot f_{c} \cdot \exp \left\{s_{f}\left[1-\left(\frac{28-t_{f s} / t_{1}}{\left(t-t_{f s}\right) / t_{1}}\right)^{0.5}\right]\right\}
$$

ヤング係数発現

$$
E(t)=a_{E} \cdot E_{c} \cdot \exp \left\{s_{E}\left[1-\left(\frac{28-t_{f s} / t_{1}}{\left(t-t_{f s}\right) / t_{1}}\right)^{0.5}\right]\right\}
$$

ここに、 $a_{f}, a_{E}=$ 標準養生供試体に対する圧縮強度とヤング係数の発 現低減率、 $s_{f} s_{E}=$ 圧縮強度とヤング係数の発現係数、 $t_{f}=$ 凝結の終結 時間(日)であり、その他は(4)、(5)式と同じである。

図一5に、力学特性の測定値と回㷌したモデル曲線を示す。ここ で、压縮強度の発現係数と発現低隇率は、部材温度履歴を受けた供 試体の測定值を最小二乗法で回帰して求めているが、ヤング係数の
発現係数は、後述する圧縮強度発現係数との関係式から求めてい る。なお、回㷌にあたり凝結の終結時間は標準養生における実測値 を用いた。

モデル曲線は、圧縮強度発現、ヤング係数発現とも温度履歴に係 わらず良好に再現できている。BPCの標準養生材齢91日の特性值は モデルよりもかなり大きくなっているものの、部材温度履歴を受け た材齢91日の特性值とモデルはよく合致していることから、実部材 の特性発現を予測することを前提とした標準養生モデル曲線として は適当と考えられる。BPCにおいて、部材温度履歴を受けた供試体 の材齢91日における力学特性值が標染養生供試体の值よりもかなり 小さくなるのは、おそらく自己乾燥による水和の停滞が原因と考え られる。以上から、各発現係数と発現低隇率の一般化ができれば、 標準養生材齢28日における特性値ならびに凝結の終結時間を適切に 設定することで、構造部材の圧縮強度およびヤング係数発現を予測 できることになる。なお、低隇率は、圧縮強度ではOPCで $0.82 、$ BPCで 0.94 とっているが、ヤング係数では特に考慮する必要はな いと考えられた。

\section{3. 実験2}

\section{1 概要}

実験2では、表-4、表一-5に示す、5種類のコンクリートについて 標準養生供試体の力学特性を測定し、水セメント比掞よびセメント の種類が力学特性発現に及ぼす影響について検討した。測定項目、 方法は実験1に準じている。

\section{2 結果および考察}

図一6に測定結果と最終的に求められた発現モデル曲線を示す。 いずれのモデル曲線も測定值を良好に再現している。ここで、圧縮 
強度発現係数 $s_{f}$ は(6)式で回㷌して求めているが、ヤング係数発現 $s_{E}$ は次式の関係から求めている。

$$
s_{E}=0.5 s_{f}-0.025
$$

これは、実験 1 の結果も含め、ヤング係数発現を(7)式で回帰して圧 縮強度発現係数との関係を検討した結果、図一7のように高い相関 が得られたことによる。なお、本来のCEB-FIP Model Code 90にお ける関係は $s_{E}=0.5 s_{f}$ である。

\section{表-4 実験2の使用材料}

\begin{tabular}{|c|c|c|}
\hline 材料 & 記号 & 種類、物性 \\
\hline \multirow{3}{*}{ セメント } & OP & $\begin{array}{l}\text { 普通ポルトランドセメント } \\
\text { 比重3.15、比表面積 } 3,270 \mathrm{~cm}^{2} / \mathrm{g}\end{array}$ \\
\hline & $\mathrm{BP}$ & $\begin{array}{l}\text { 高ビーライト系セメント } \\
\text { 比重3.20、比表面積 } 4,110 \mathrm{~cm}{ }^{2} / \mathrm{g} \\
\end{array}$ \\
\hline & BB & $\begin{array}{l}\text { 高炉セメントB種 } \\
\text { 比重3.04、比表面樻 } 3,850 \mathrm{~cm}{ }^{2} / \mathrm{g}\end{array}$ \\
\hline 細骨材 & $S$ & $\begin{array}{l}\text { 陸砂 } \\
\text { 比重 } 2.59 \text { 、吸水率 } 1.63 \% \text { 、粗粒率 } 2.80\end{array}$ \\
\hline 粗骨材 & $\bar{G}$ & $\begin{array}{l}\text { 硬質砂岩砕石（最大粒径20mm） } \\
\text { 比重2.65、吸水率0.60\%、粗粒率6.75 }\end{array}$ \\
\hline \multirow[t]{2}{*}{ 混和剤 } & $\mathrm{SP}$ & ポリカルボン酸系高性能AE減水剤 \\
\hline & $\mathrm{AE}$ & AE減水剂（OP55のみ） \\
\hline
\end{tabular}

表一5 実倹2の調合

\begin{tabular}{|c|c|c|c|c|c|c|c|c|}
\hline \multirow[t]{2}{*}{ 種類 } & \multirow{2}{*}{$\begin{array}{c}\mathrm{W} / \mathrm{C} \\
\%\end{array}$} & \multirow{2}{*}{$\begin{array}{l}\text { s/a } \\
(\%)\end{array}$} & W & C & S & $\mathrm{G}$ & \multirow{2}{*}{$\begin{array}{c}f_{c} \\
\left(N / \mathrm{mm}^{2}\right)\end{array}$} & \multirow{2}{*}{$\begin{array}{c}\mathrm{E}_{\mathrm{c}} \\
\left(\times 10^{4} \mathrm{~N} / \mathrm{mm}^{2}\right)\end{array}$} \\
\hline & & & \multicolumn{4}{|c|}{$\mathrm{kg} / \mathrm{m}^{3}$} & & \\
\hline P27 & 27 & 42.9 & 163 & 604 & 686 & 930 & 93.9 & 3.70 \\
\hline OP40 & 40 & 45.0 & 168 & 420 & 780 & 975 & 69.5 & 3.48 \\
\hline OP55 & 55 & 48.1 & 182 & 331 & 834 & 920 & 36.7 & 3.01 \\
\hline BP27 & 27 & 43.1 & 163 & 604 & 692 & 930 & 103 & 3.83 \\
\hline B27 & 27 & 42.2 & 163 & 604 & 666 & 930 & $\overline{10}$ & 3.91 \\
\hline
\end{tabular}
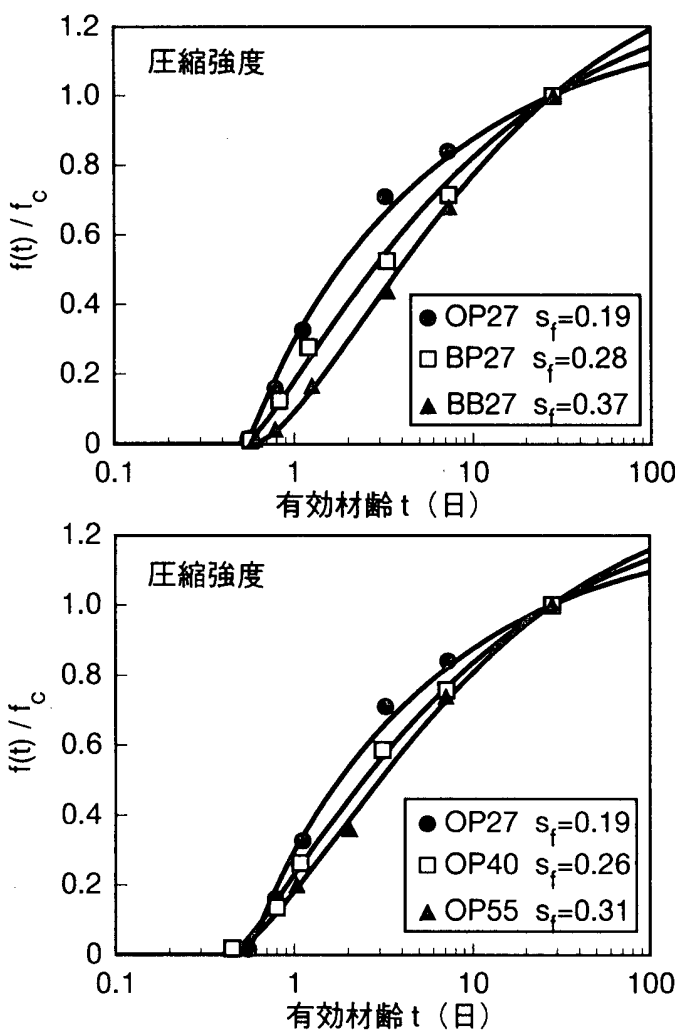
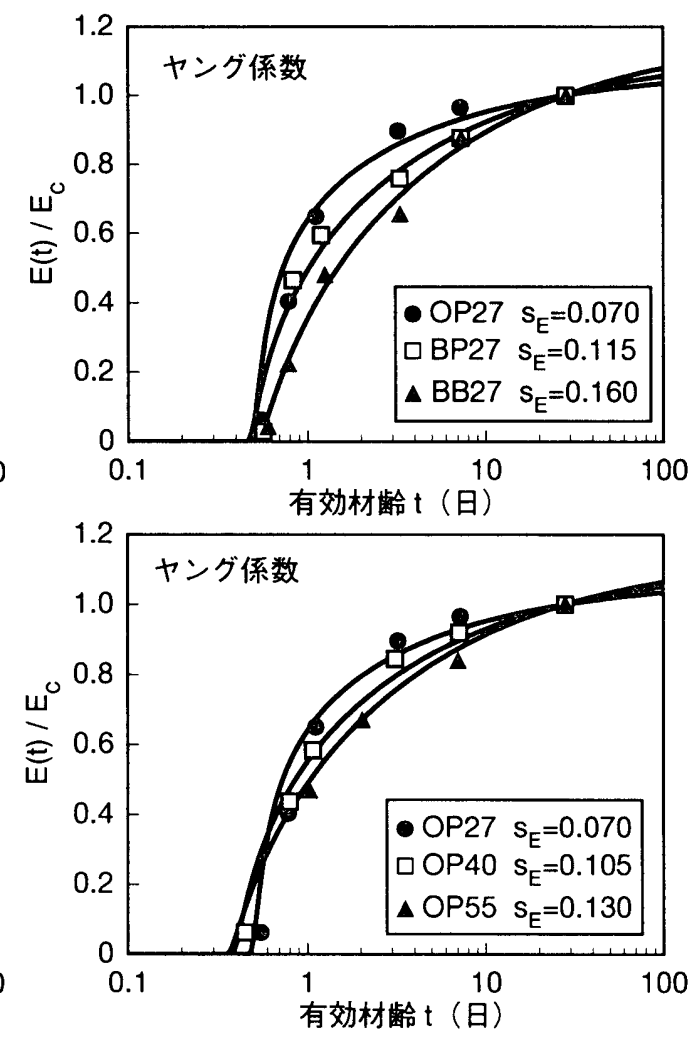

次に、図ー8に示すように、普通ポルトランドセメントの $s_{f}$ は水 セメント比が大きくなるほど大きくなり、本実験範囲では次式の 関係が得られた。

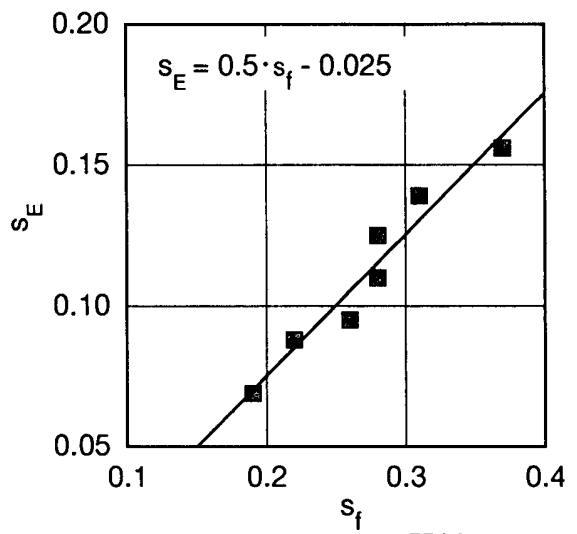

図一 $s_{1}$ と $s_{E}$ の関係

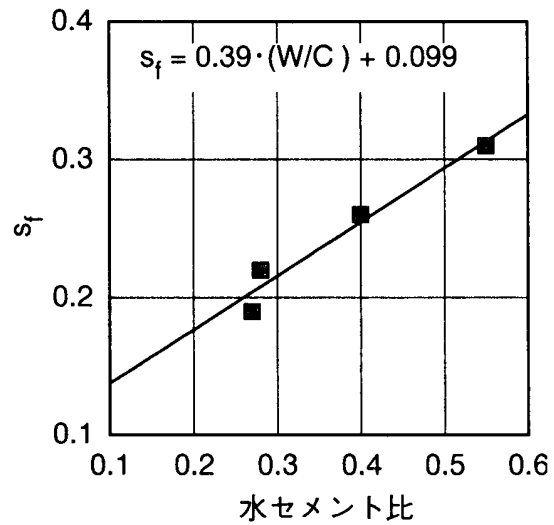

図一8 水セメント比と $\mathrm{s}_{\mathrm{f}}$ の関係：普通ポルトラントセメトの場合

図一6 圧縮強度およびヤング係数の測定値と発現モデル：実験2 


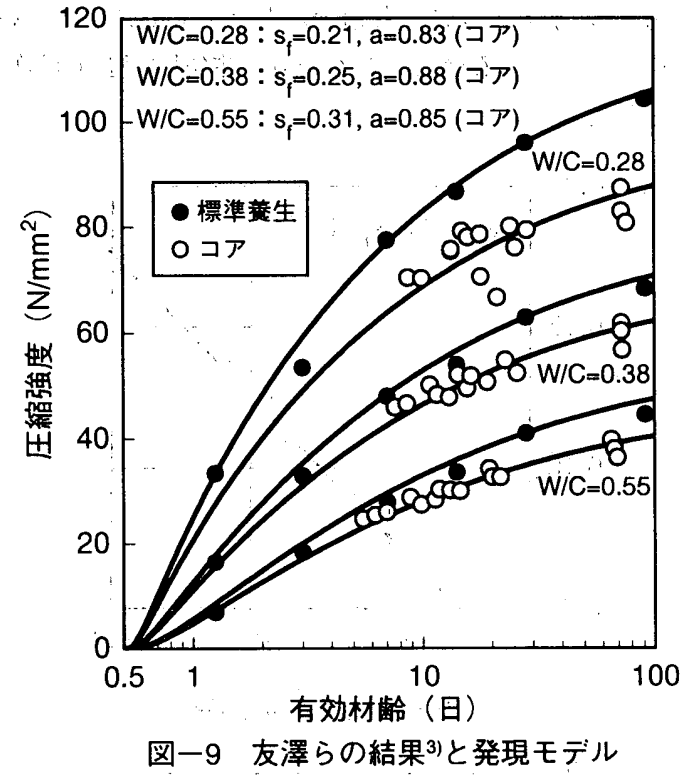

$s_{f}=0.39(W / C)+0.099$

また、セメントの種類が異なるOP27、BP27、BB27の高強度コンク リートのs $s_{f}$ 、それぞれ0.19、0.28、0.37となっている。CEB-FIP Model Code 90では、発現係数sはセメントの種類のみで決定されて いるが、このように、水セメント比ならびにセメントの種類の両要 因の影響で発現係数は異なってくることがわかる。なお、(8)および (9)式の関係は、今後より多くのデータに基づいて回帰することで、 一般性の高いものになると考えられる。

\section{4. 提案モデルの検証}

友澤らは、普通ポルトランドセメントを用いた水セメント比 $0.28 、 0.38 、 0.55$ のコンリートについて、温度履歴を受けた模擬 試験体のコア供試体および標準養生供試体の圧縮強度発現と相当材 齢の関係について報告している3)。模擬試験体は4面を断熱した1× $0.5 \times 0.9 \mathrm{~m}$ の大きさで、最高到達温度は、水セメント比 $0.28 、 0.38$ 、 0.55 でそれぞれ約 $70^{\circ} \mathrm{C} 、 60^{\circ} \mathrm{C} 、 50^{\circ} \mathrm{C}$ となている。報告されている 関係図を、若干の相違はあると思われるが、相当材齢をそのまま有 効材齢と見なして示したのが図一9である。

同図における標染養生のモデル曲線において、発現係数は水セメ ント比と(9)式の関係から求め、㠜結の終結時間はいずれも0.5日と 仮定している。また、コア供試体のモデルは、さらに発現低減率を 変数として回帰することで求めている。いずれの水セメント比につ いても、標準養生、温度履歴を受けたコア供試体とも発現モデルは 測定値を良好に再現しており、本提案モデルの妥当性が確認でき る。また、これらの結果から、本提案モデルは高強度コンクリート のみならず普通強度レベルのマスコンクり一トに対しても有効であ ること、普通ポルトランドセメントの場合の発現低減率は水セメン ト比に係わらずおおよそ0.85であること、コンクリートの凝結の終 結時間としては暫定的に 0.5 日が採用できることなどがわかる。

5. まとめ

初期高温履歴を受ける高強度コンクリート構造部材の初期材齢か ら材齢91日程度までの力学特性（圧縮強度ならびにヤング係数）発
現モデルを提案することを目的として行った本研究の結果は以下の ようにまとめられる。

1)CEB-FIPの有効材齢（または相当材齢）をマチュリティとするこ とで、温度履歴を受けた構造部材の力学特性発現は、材齢7日，程 度までの初期材齢では、標準養生供試体の特性発現とほとんど同、 一の曲線で表すことができる。

2)CEB-FIPの力学特性発現モデルに、発現の起点としての凝結の終 結時間、ならびに標準養生供試体に対する発現低滅率をパラメー タに加えた改良モデルは、高強度コンクリートの標準養生供試体 ならびに構造部材の力学特性発現を良好に再現できる。为学特性 発現係数と発現低隇率の一般化ができれば、標準養生材齢28日に おける特性值と凝結の終結時間，を適切に設定することで、初期高 温履歴を受ける構造部材の力学特性発現の予測が可能である。 3)改良モデルにおける圧縮強度とヤシグ係数の両発現係数には、コ ンクリートの種類に係わらず、一次の相関関係が成立する。ま た、水セメント比と圧縮強度発現係数にも、普通ボルトランドセ メントで一次の相関関係が認められた。これらの関係式はより多 くのデー多を蓄積することで一般性を高めることが可能と考えら れる。

4)改良モデルにおける構造部材の標準養生供試体に対する発現低減 率は、压縮強度については普通ポルトランドセメントで 0.85 前 後、高ビーライト采セメントで約0.95であったが、ヤング係数に ついては特に考慮する必要はなかった。たたし、これら值の一般 性ついてはさらに検討を要する。

以上の結果から、高強度コンクリートの標準養生供試体ならびに 実構造部材の初期材龄から材齢91日程度までの圧縮強度ならびにヤ ング係数発現モデル式を提案した。また、本モデルは普通強度レべ ルのマスコンクリートなどに対しても有效と考えられる。

\section{謝辞}

本研究の発想は、（社）日本コンクリート工学協会「自己収縮研 究委員会」WG3の活動を通じて得られたものである。広島大学田 澤栄一教授 (委員長) 、宇都宮大学佐藤良一教授（WG3主査）を はじめとした委員会のメンバーに謝意を表する。また、実験デー夕 の一部は住宅都市整備公団と清水建設（株）との共同研究で得られ たものであることを付記する。

\section{参考文献}

1)CEB-FIP Model Code 1990, Comité Euro-international du Béton, 1990 2)Freiesleben Hansen, P., and Pedersen, J.: Maturity of Computer for Controlled Curing and Hardening of Concrete, Nordisk Betong (Stockholm), V. 21, pp. 19-34, 1977

3)友澤史紀, 牛島 栄: 最近の積算温度方式の発展とその応用, セメント・コ ンタリート, No.527, pp. 66-73, 1991

4)自己収縮研究委員会報告青, 日本コンクリート工学協会, pp. 93-113, 1996 5)地濃茂雄, 仕入豊和: コンクリートの㤝度発現性状におよほす温度履歷条 件 $\left(20 \sim 90^{\circ} \mathrm{C}\right)$ の影䇾, 日本建築学会論文報告集, 第337号, pp. 8-13, 1984 6)牛島 栄, 酒井芳文, 原田和樹: 高強度コンクリートの内部温度履歷が強 度発現に及ほす影響, セメント・コンクリート論文集, No. 46, pp. 93-113, 1992 